\title{
A HONVÉD HUSZÁR DÍSZALEGYSÉG LÉTREHOZÁSA ÉS TERVEZETT RÉSZVÉTELE AZ ÁLLAMI PROTOKOLLÁRIS FELADATOKBAN
}

\author{
DOI: $10.35926 / \mathrm{HSZ} .2021 .6 .7$
}

ÖSSzEFOGLALÓ: A Magyar Honvédség alakulatai közül a Szent Korona teljes körü őrzés-védelmét és az állami katonai protokollesemények díszelgő biztosítását végrehajtó 32. Nemzeti Honvéd Díszegység állományában hozták létre a Honvéd Huszár Díszalegységet. Azállami protokolleseményeken megjelenő díszegység kötelékében a honvédhuszárok magas politikai, diplomáciai pozíciót betöltő hazai és külföldi személyek elött is reprezentálják nemzetközileg is jól ismert nemzeti lovaskultúránkat, a világhírü és hungarikummá minősített magyar huszárságot, illetve magas színvonalú lótenyésztésünket. A tanulmány a honvédhuszárság létrehozásának folyamatát és lehetséges feladatait protokolláris szempontból igyekszik megvilágítani.

KULCSSZAVAK: huszárság, állami protokoll, díszelgési feladatok

\section{BEVEZETÉS}

A Magyar Honvédség feladatai közül a honvédelemröl és a Magyar Honvédségről, valamint a különleges jogrendben bevezethető intézkedésekről szóló 2011. évi CXIII. törvény 36. § (1) b) és a (2) c) pontjai két olyan különleges feladatot - fegyverhasználati joggal a Szent Korona örzését és fegyverhasználati jog nélkül az állami protokolláris feladatok teljesítésében való részvételt - határoznak meg, amelyek külön-külön is igénylik, hogy csak ezen feladatok végrehajtására a magyar haderőstruktúrában egy speciális rendeltetéssel bíró katonai alakulat müködjön. A Magyar Honvédség által védendő létesítmények kijelöléséröl, valamint a magyar állam folytonosságát és függetlenségét megtestesítő ereklyék köréröl, illetve az őrzésükre vonatkozó szabályokról szóló 78/2011. (V. 12.) Korm. rendelet alapján a mai Magyar Honvédségben a 32. Nemzeti Honvéd Díszegység ${ }^{1}$ az a katonai szervezet, amelynek alegységei - ország és világ előtt - a nemzet ünnep- és gyásznapjain, az állami és katonai eseményeken, a kijelölt objektumok díszőrszolgálatának ellátásával megjelenítik a mai magyar haderő nemzeti egységét és ősi intézményét.

A 32. Nemzeti Honvéd Díszegységet 2011. november 1-jén alakították meg. A Honvéd Koronaörség fegyverhasználati joggal látja el az Országházban - vagy a kijelölt helyen - a Szent Korona és a levont nemzeti lobogó őrzését, közremüködik a nemzeti és állami ünnepeken, továbbá a diplomáciai és egyházi eseményeken. A Honvéd Palotaőrség végzi Magyarország

\footnotetext{
Az alakulat bemutató írása az MH BHD honlapján érhető el: https://bhd.honvedseg.hu/rovat/32_nemzeti_honved diszegyseg (Letöltés időpontja: 2021. 04. 03.)
} 
köztársasági elnökének állami és protokolláris feladataival kapcsolatos katonai díszelgési feladatokat, díszőrszolgálatot lát el a Köztársasági Elnöki Hivatalnak otthont adó Sándor-palotában, közremüködik a nemzeti és állami ünnepeken, diplomáciai eseményeken. A Honvéd Díszzászlóalj Magyarország nemzeti és állami ünnepségein, diplomáciai, társadalmi és katonai rendezvényein, illetve kegyeleti eseményeken jeleníti meg a magyar honvédet, díszőrszolgálatot lát el Magyarország felvont lobogójánál, végzi a katonai tiszteletadással kapcsolatos feladatokat, külföldi állami és katonai vezetök katonai tiszteletadással történő fogadását, az elöljáró intézkedése szerinti kegyeleti feladatokat. A Kincsem Nemzeti Lovas Program ${ }^{2}$ keretén belül 2020-ban megalakított Honvéd Huszár Díszalegység ${ }^{3}$ az állami és katonai protokoll lovasított díszelgési feladatait, valamint az országmárka szerves részét képező lovaságazat ${ }^{4}$ és a több évszázados magyar katonai lovaskultúra megőrzését és bemutatását hajtja végre. A honvédhuszárok lóháton vesznek részt az állami, katonai protokolláris, turisztikai és lovaseseményeken, Honvéd Huszár Lovasiskolát működtetnek a Lipicai Lovasközpontban, illetve a kijelölt helyen magyar stílusú huszárlókiképzési bemutatókat tartanak és nyári huszártáborokat szerveznek. A tanulmány a továbbiakban ezen díszalegység létrehozását és tervezett protokolláris feladatait ismerteti.

\section{NEMZETKÖZI KITEKINTÉS}

A magyar közvélemény, de a hadtudomány képviselői előtt sem igazán ismert az a tény, hogy a NATO-ban ma is léteznek aktív hadrendi elemként modern technikai eszközökkel felszerelt huszárezredek. Ilyen Dániában a Gardehusarregimentet (Gárdahuszárezred - magyar alapítású, három névtelen magyar huszártiszt, 1614), ${ }^{5}$ Franciaországban a 1er régiment de hussards parachutistes (1. ejtőernyős huszárezred - magyar alapítású, gróf Bercsényi László Ignác, 1720), ${ }^{6}$ a 2e régiment de hussards (2. huszárezred - magyar alapítású, gróf Esterházy Bálint József, 1735), ${ }^{7}$ a 3e régiment de hussards (3. huszárezred - magyar alapítású, gróf Esterházy Bálint Miklós, 1764), ${ }^{8}$ Hollandiában a Regiment Huzaren van Boreel (Boreel huszárezred - magyar mintára alapított, 1813), ${ }^{9}$ Kanadában

2 Kincsem - Nemzeti Lovas Program. Közigazgatási és Igazságügyi Minisztérium, 2012. http://mlosz.hu/nlp/nlp. pdf (Letöltés időpontja: 2021. 04. 12.)

3 Uo. 3.6.2.

4 A Nemzeti Lovas Programban meghatározott feladatokról és a kiemelt feladatok végrehajtásához szükséges intézkedésekről szóló 1061/2012. (III. 12.) Korm. határozat. Magyar Közlöny, 2012/29. http://www.kozlonyok.hu/ nkonline/index.php?menuindex $=200 \&$ pageindex $=$ kozltart\&ev=2012\&szam $=29$ (Letöltés időpontja: 2021.04 .02 .)

5 Om Gardehusarregimentet (A Gárdahuszárezredröl). https://forsvaret.dk/da/organisation/haeren/gardehusar regimentet/ (Letöltés időpontja: 2021. 02. 05.)

6 1er régiment de hussards parachutistes (Az 1. ejtőernyős huszárezred). https://www.defense.gouv.fr/terre/larmee-de-terre/le-niveau-divisionnaire/3e-division/11e-brigade-parachutiste/regiments/1er-regiment-de-hussardsparachutistes (Letöltés időpontja: 2021. 02. 05.)

7 2e régiment de hussards (A 2. huszárezred). https://www.defense.gouv.fr/english/node_64/1-armee-de-terre/leniveau-divisionnaire/commandement-du-renseignement/2e-regiment-de-hussards (Letöltés időpontja: 2021. 03. 31.)

8 3e régiment de hussards (A 3. huszárezred). https://www.sengager.fr/regiments/3e-regiment-de-hussards (Letöltés időpontja: 2021. 03. 30.)

9 Regiment Huzaren van Boreel (A Boreel huszárezred). https://www.huzarenvanboreel.nl/ (Letöltés idöpontja: 2021. 03.30.) 
a 8th Canadian Hussars (8. kanadai huszárezred - magyar mintára alapított, 1848), ${ }^{10}$ a Sherbrooke Hussars (Sherbrooke-i huszárezred - magyar mintára alapított, 1866), ${ }^{11}$ a Royal Canadian Hussars (Királyi kanadai huszárezred - magyar mintára alapított, 1879), ${ }^{12}$ a 1st Hussars (1. huszárezred - magyar mintára alapított, 1888), ${ }^{13}$ az Egyesült Királyságban a The Queen's Royal Hussars (a Királynő huszárezrede) ${ }^{14}$ és a The King's Royal Hussars (a Király huszárezrede)..$^{15}$

Ezen alakulatok közül a dán haderő Slagelse-ben állomásozó Gárdahuszárezredének állományában található egy huszárszázad, ${ }^{16}$ amely lóháton végez protokolláris feladatokat. A gárdaezred vonatkozásában érdekesség, hogy történetét a hivatalos oklevelek alapján $1614-\mathrm{re}^{17}$ vezetik vissza, és önmagukat a világ legrégibb huszárezredének tartják. Történelmükben magyar huszárok is fontos szerepet játszottak, mivel IV. Keresztély dán-norvég király (1588-1648) Báthory István lengyel király (1575-1586) halála után testőrségének három magyar huszártisztjét fogadta szolgálatába, akik a király körül testőri feladatokat végeztek. A testörcsapat bővítését követően is mindössze három magyar tisztböl, egy őrmesterből, két káplárból, egy trombitásból és harminc huszárból állt. A mai lovasított alegység két huszárszázadból (századonként 40 fö), kiképzési részlegből, zenei részlegből, ellátó és karbantartó szakaszokból áll, összesen 75 lóval rendelkezik. A dán királyi ház protokolleseményein vesznek részt, lóháton és gyalog protokoll őrzés-védelmi (például díszőrszolgálat, díszsorfal, díszkíséret) feladatokat látnak el, ugyanakkor különleges jogrendi helyzetben a Királyi Testőrséget erősítik meg. A huszárság hagyományait és szokásait nagyon komolyan ápolják, díszegyenruhájuk (1. ábra) közvetlenül visszavezethető az V. Frigyes dán és norvég uralkodó (1723-1766) által 1762. február 10-én létrehozott huszárezredhez, amely sikeresen harcolt a kozákokkal az Oroszország elleni háborúban. Érdekesség még, hogy csak ennél a huszárszázadnál fogadnak egyéves szolgálatra „önkénteseket”, míg a Gárdahuszárezred többi, modern haditechnikával felszerelt alegysége szerződéses katonákból áll.

10 8th Canadian Hussars (A 8. kanadai huszárezred). http://www.army-armee.forces.gc.ca/en/5-canadian-division/8canadian-hussars/index.page (Letöltés időpontja: 2021. 03. 30.)

${ }^{11}$ Sherbrooke Hussars (A Sherbrooke-i huszárezred). http://www.army-armee.forces.gc.ca/en/2-canadian-division/ the-sherbrooke-hussars/index.page (Letöltés időpontja: 2021. 03. 31.)

${ }^{12}$ The Royal Canadian Hussars (A Királyi kanadai huszárezred). http://www.army-armee.forces.gc.ca/en/2-canadiandivision/the-royal-canadian-hussars/index.page (Letöltés időpontja: 2021. 03. 30.)

${ }_{13}$ 1st Hussars (Az 1. huszárezred). http://www.army-armee.forces.gc.ca/en/4-canadian-division/1-hussars/index. page (Letöltés időpontja: 2021. 03. 31.)

14 The Queen's Royal Hussars (A Királynő huszárezrede). https://www.army.mod.uk/who-we-are/corps-regimentsand-units/royal-armoured-corps/queens-royal-hussars/ (Letöltés időpontja: 2021. 04. 02.)

${ }^{15}$ The King's Royal Hussars (A Király huszárezrede). https://www.army.mod.uk/who-we-are/corps-regiments-andunits/royal-armoured-corps/kings-royal-hussars/ (Letöltés időpontja: 2019. 09. 02.)

${ }^{16}$ Gardehusarregimentets Hesteskadron (Gárdahuszárezred lovasított svadron). https://karriere.forsvaret.dk/ uddannelse/interne-uddannelser/hesteskadronens-varnepligt/ (Letöltés időpontja: 2021. 03. 20.)

${ }^{17}$ Om Gardehusarregimentet (A Gárdahuszárezredröl). https://forsvaret.dk/da/organisation/haeren/gardehusar regimentet/om-os/ (Letöltés időpontja: 2021. 03.31.) 


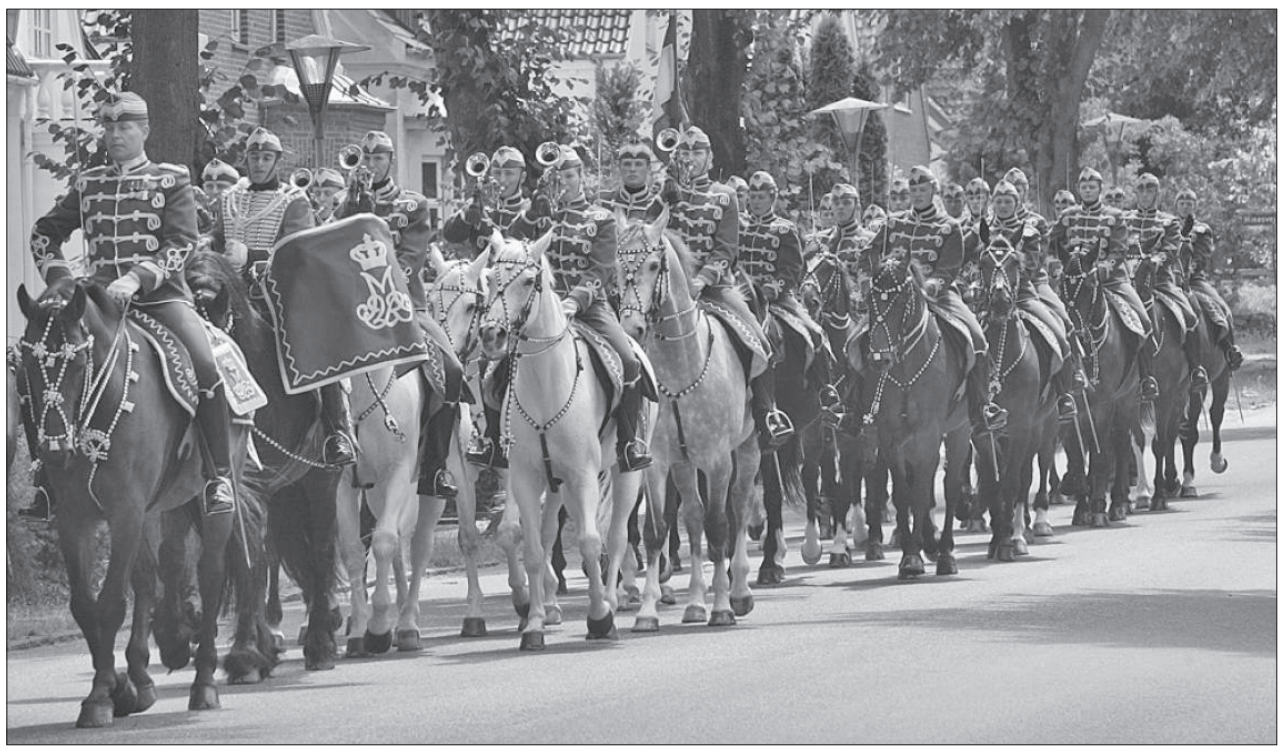

1. ábra A dán Gárdahuszárezred protokollfeladatokra alkalmas huszárszázadának egyenruhája

Forrás: https://portals.clio.me/dk/historie/7-9/emner/historiske-temaer/lokalhistorie-sjaelland/introduktion/ (Letöltés idöpontja: 2020. 11. 06.)

Az Egyesült Királyságban ceremoniális feladatokra az Udvari Lovasság lovasított ezrede (Household Cavalry Mounted Regiment) $^{18}$ van kijelölve. Ez az ezred 250 lóval rendelkezik, és alaprendeltetési feladata a királyi ház tradicionális lovas testőrségének (The Queen’s Life Guard) 24 órás ellátása a Whitehallban, az udvar ceremoniális és egyéb hivatalos diplomáciai eseményeinek (pl. a királynő születésnapi díszszemléje, államföi látogatások), a kormányzati, önkormányzati események (pl. a parlament nyitóülése, föpolgármesteri szemle) díszelgő biztosítása lóháton. Ezeken kívül feladatuk még zenés lovassági bemutatók megtartása és a brit katonai lovaskultúra megjelenítése a nemzeti lovaseseményeken, -versenyeken, amelyeken az alakulat tagjai aktívan versenyeznek is. Képességüket tekintve a napi lovas testör díszőrszolgálatokkal és különleges bemutató csoportjával jelentősen hozzájárulnak az udvari és a nemzetközi diplomáciai események fényének emeléséhez, a Londonba látogató turisták állandó programokkal való kiszolgálásához, illetve a katonai lovaskultúra megjelenítéséhez és ápolásához. Érdekesség, hogy a páncélosfelderítö-ezred (hagyományos nevén Household Cavalry Regiment) állományát a lovasított ezredhez való kétéves vezényléssel rotálják. 15 hét alatt készítik fel őket a lovasított ceremoniális feladatok ellátására, majd a két év letelte után visszatérnek a páncélosfelderítö-ezredhez. Létszámhiányuk nem számottevő, a Windsorban tartott lovaskiképzésen átlagosan 10-20 fö vesz részt, és az újoncok 90\%-a lóval azelött még nem találkozott. Évente 10-20 fekete színủ lovat szereznek be - elsősorban Írországból -, és 15 hét alatt készítik fel öket a díszelgési feladatokra.

${ }^{18}$ Household Cavalry (Udvari Lovasság). https:/www.army.mod.uk/who-we-are/corps-regiments-and-units/royalarmoured-corps/household-cavalry/ (Letöltés időpontja: 2020. 04. 02.) 


\section{A HONVÉD HUSZÁR DÍSZALEGYSÉG LÉTREHOZÁSA}

A „Budapest és az agglomeráció fejlesztésével összefüggő állami feladatokról, valamint egyes fejlesztések megvalósításáról [...]" szóló 2018. évi XLIX. törvény feladatmeghatározása alapján - a Nemzeti Hauszmann Program keretében - megújuló Budai Palotanegyed értékmegőrző és méltó használatának, fenntartásának és bemutatásának, fenntartható fejlesztésének, valamint tervszerü és egységes szemléletű helyreállításának biztosítása kiemelt jelentőségű közfeladat.

A Honvédelmi Minisztérium, kapcsolódva a Kincsem Nemzeti Lovas Programhoz, a honvédelemről és a Magyar Honvédségről, valamint a különleges jogrendben bevezethető intézkedésekről szóló 2011. évi CXIII. törvény 36. § (2) c) és a Magyar Honvédség által védendő létesítmények kijelöléséröl, valamint a magyar állam folytonosságát és függetlenségét megtestesítő ereklyék köréről és az őrzésükre vonatkozó szabályokról szóló 78/2011. (V. 12.) Korm. rendelet 3. § (1) pontjaiban meghatározott feladatok végrehajtására-a Miniszterelnökség felkérésére - munkacsoportot ${ }^{19}$ hozott létre 2015 februárjában, amelynek alapvető feladata volt, hogy elökészítse a Magyar Honvédség részeként a Honvéd Huszár Díszalegység (a továbbiakban: HHD) létrehozását és müködtetését. A munkacsoport 2015 júniusára kidolgozta a tárcaszintű koncepciót. A további előkészítési és tervezési folyamat vezetését a Honvéd Vezérkar vette át, illetve az MH vitéz Szurmay Sándor Budapest Helyőrség Dandár folytatta. ${ }^{20}$

\section{A kidolgozói munka során az alábbi javaslatokat fogalmazták meg.21}

- A Magyar Honvédség közmegbecsültségének megfelelően vegyen részt kiemelt közfeladatok, különösen a Nemzeti Hauszmann Program és a Kincsem Nemzeti Lovasprogram megvalósításában;

- A Magyar Honvédség meglévő katonai képességeinek kihasználásával, ill. nemzetközi és nemzeti elismertségen nyugvó tradicionális képesség újraélesztésével növelje társadalmi láthatóságát;

- A Budai Palotanegyed történelmi arculatának és hagyományainak megfelelő katonai feladatok végrehajtásával a Magyar Honvédség járuljon hozzá:

- lovasított és gyalogos protokolláris objektumőrzési és díszelgési feladatok végrehajtásával a biztonság megörzéséhez és növeléséhez,

- a diplomáciai és más protokollesemények színvonalának emeléséhez,

- a ceremoniális katonai jelenléttel és programelemekkel az idegenforgalom fejlesztéséhez,

- a magyar katonai lovaskultúra, ill. lófajták bemutatásával a magyar lótenyésztés és értékesítés fejlesztéséhez,

- a Kincsem Nemzeti Lovas Program megvalósításához,

- Magyarország Nemzeti Lovas Díszegységének a 24/2005. (BK 14.) BM utasításban meghatározott feladataihoz;

- A Honvéd Huszár Díszalegység kezdeti müveleti készenlétét 2021. március 15-re érje el;

- A honvédhuszárság feladatait békeidőszakban alapvetően protokolláris, az attól eltérő helyzetben a huszárság eredeti feladatrendszerén belül objektumbiztosítási feladatokra kell tervezni és felkészíteni;

\footnotetext{
${ }^{19}$ HM munkabizottsági jegyzőkönyv, 2015. 02. 20. Jkv sz. 61-74/2015. Vezeti Kun Szabó István vezérőrnagy (HM TKHÁT), helyettese Korom Ferenc dandártábornok (HVK HDMCSF).

20 284/2018. sz. HVKF parancs. http://www.kozlonyok.hu/kozlonyok/index.php?m=0\&p=kozltart\&ev=2018\&sza $\mathrm{m}=9 \& \mathrm{k}=13$ (Letöltés időpontja: 2021. 04. 12.)

${ }^{21}$ MH BHD dandárparancsnok írásos jelentése. Nytsz. 510-20/2018.
} 
- A lóháton megjelenő honvédhuszárság egyidejüleg reprezentálja a nemzet katonai lovaskultúráját, hagyományait és a megújuló Magyar Honvédséget;

- Magyarország Nemzeti Lovas Díszegységével együttműködve vagy önállóan vegyen részt az állami, katonai protokolláris, kegyeleti és egyházi díszelgési feladatok teljesítésében;

- járuljon hozzá az országimázs, a nemzeti öntudat erösítéséhez, a honvéd tisztképzés és katonai pályára irányítás, az iskolai lovasoktatás és lovaglás népszerüsítéséhez, a huszár hagyományőrzés támogatásához;

- Katonadiplomáciai szempontból - a HM Nemzetközi Főosztály irányítása és az MHP szakmai vezetése mellett - kapcsolja össze a NATO-tagországokban a 21. században is müködő, magyarok által alapított vagy magyar mintára szervezett, 11 modern huszárezredet, valamint a müködő tradicionális lovassági alakulatokat;

- Társadalmi kapcsolatok vonatkozásában - a HM HOÁT irányítása és az MHP szakmai vezetése mellett - járuljon hozzá az iskolai lovasoktatás és lovaglás népszerüsítéséhez, a huszár hagyományőrzéshez;

- A honvédhuszárok egyéni és kötelékben történő megjelenésükkel a köztudatban élő, hungarikummá minősített, magyar huszárra jellemző nemzeti jellegeket, jegyeket hangsúlyozzák;

- A honvédhuszárok díszöltözeti formái a nemzeti színeket jelenítsék meg, a fehér ezüstszínnel váltható ki. Kiemelt díszelgési feladatokon díszöltözetük harmonizáljon a Nemzeti Lovas Díszegység öltözetével. A napi szolgálati díszöltözetük a Hauszmann-féle eredeti átépítést követően a Budavári Palotában szolgálatot teljesített lovas alakulat jellegzetességeit hangsúlyozza;

- A lovasított díszelgési feladatokat alapvetően szürke színü, lipicai fajtához tartozó, állami ménesgazdaság által tenyésztett lovakkal kell tervezni, amelyek nem kerülnek a HM tulajdonába. Az állami tulajdonú lovakat költségvetési szervek közötti kölcsönös elönyöket biztosító, térítésmentes használatba adási megállapodásban kell használatba venni. A lovak és a személyi állomány lovaskiképzésére huszár lovasiskolát kell müködtetni egy állami lovasintézményben. A kiképzett huszárlovak értékesíthetők az állam által;

- A felállítást 2020. július 1-től az alábbi három ütemben, a meglévő üres beosztások felhasználásával és feltöltésével kell tervezni:

I. ütem: Huszár Előkészítő törzs felállítása - 2020. július 1. - 2020. október 1.

II. ütem: Huszár Előkészítő részleg felállítása - 2020. október 1. - 2021. március 15.

III. ütem: Honvéd Huszár Díszalegység müködtetése - 2021. március 15-től;

- A Honvéd Huszár Díszalegység szervezeti tagozódása a 32. Nemzeti Honvéd Díszegység állományába történjen, végrehajtó alegységként az alábbi összetételben:

- Parancsnokság: a napi szolgálati tevékenység tervezési, szervezési, vezetési és koordinációs tevékenységének végzése, állategészségügyi biztosítás,

- Kiképzési részleg - Huszár Lovas Iskola (Szilvásvárad) -, lókiképzés és lovasoktatás, lovarda szakmai müködtetése, igény szerint huszárbemutatók a Lipicai Lovas Központban,

- Huszár szakasz(ok): napi belső és külső szolgálatok, protokollkirendelések, díszelgési feladatok, huszár alaki bemutatók végrehajtása,

- Szállásmesteri (Logisztikai) részleg: a HHD alaprendeltetési feladatainak logisztikai biztosítása, lovardakiszolgálási feladatok. 
A fenti javaslatokat a legmagasabb vezetői szinten elfogadták, a felállításról pedig 2019 januárjában honvédelmi miniszteri utasítás ${ }^{22}$ rendelkezett. A meghatározott feladat és a jóváhagyott tervek alapján dr. Vidoven Árpád, a HM közigazgatási államtitkára és Korom Ferenc vezérezredes, a Magyar Honvédség akkori parancsnoka közös irányítása alatt elkészült a felállítás erőforrás-tervezése, a ruházati formák és lószerszámzatok felhasználói és műszaki követelményeinek meghatározása, megkezdődtek a jogszabályok, illetve a feladatrendszer áttekintése és kidolgozása, amelynek keretén belül előkészítették az együttmüködési megállapodást a lovak biztosítása céljából az Agrárminisztériummal (a továbbiakban: AM) és a szilvásváradi Állami Ménesgazdasággal (a továbbiakban: ÁMgSZ). 2020 elején Dallos Gyula, a Kincsem Nemzeti Lovas Program megújításáért és végrehajtásáért felelős miniszteri biztos ${ }^{23}$ szakmai útmutatásai alapján és Cseri Dávid, az ÁMgSZ igazgatója vezetésével megkezdődött a lipicai csikók kiválogatása és a Lipicai Lovas Központban az elhelyezési és kiképzési feltételek megteremtése. 2020. július 1-jén Dallos Gyula miniszteri biztos ünnepélyesen megnyitotta a Huszár Elökészítő Törzs kiképzését, és szimbolikusan átadásra került az első lipicai hátasló. A felkészülés megkezdődött.

\section{HONVÉD HUSZÁR DÍSZALEGYSÉG TERVEZETT PROTOKOLLÁRIS FELADATAI}

A protokoll hagyományos értelemben véve a hivatalos érintkezésben használt valamilyen szempont szerint szervezett mozgást takar, mely lehet üzleti, egyházi, katonai protokoll stb. ${ }^{24}$ A protokolláris feladatok rendkívül összetett tevékenységeket jelentenek a katonai tiszteletadással meghatározott eseményeken. „A tiszteletadás katonai formája a díszszemle, a díszmenet, vagyis amikor a díszegység tiszteletadást teljesit az arra jogosult személyiség vagy jelkép elött. Erre sor kerülhet nemzeti ünnepen zászlófelvonáskor, államfö, kormányfó érkezésekor, távozásakor, eskü, koszorúzás, emlékmüavatás alkalmával, parancsnokság átvétele, csapatzászló vagy kitüntetés átadása után [...] A díszegység megszemlélése parancsnoklási aktus, emiatt csak az teheti meg, aki parancsnoki felelösséget visel, vagyis államfö, kormányfö, honvédelmi miniszter, katonai vezetők, kivételesen hasonló rangú külföldi személyiségek is (pl. államföi látogatás alkalmával).," 25

\section{Nemzeti ünnepek rendezvényein való részvétel:}

A huszárság megjelenésével tervezett protokolláris feladatok közül kiemelkedik a nemzeti ünnepeken és gyásznapokon Magyarország lobogójának katonai tiszteletadással történő felvonásán, félárbócra engedésén, ill. levonásán való díszelgési feladat végrehajtása a 32 . Nemzeti Honvéd Díszegység gyalogságával, a Nemzeti Lovas Díszegységgel és a Központi zenekarral. A feladatra maximális létszámban jelenne meg a HHD.

\footnotetext{
22 A honvédelmi szervezetek 2019. évi feladatainak, valamint a 2020-2021. évi tevékenysége fö irányainak meghatározásáról szóló 3/2019. (I. 31.) HM utasítás. http://www.kozlonyok.hu/kozlonyok/Kozlonyok/13/PDF/2019/2. pdf (Letöltés időpontja: 2021. 02. 12.)

23 Agrárminisztérium, miniszteri biztosok. https://kormany.hu/agrarminiszterium/miniszteri-biztosok (Letöltés időpontja: 2021. 04. 12.)

${ }^{24}$ Görög Ibolya: Protokoll az életem. Athenaeum Kiadó, Budapest, 2017.

${ }^{25}$ Diplomáciai lexikon. A nemzetközi kapcsolatok kézikönyve. Éghajlat Könyvkiadó, Budapest, 2018, 621. http:// real.mtak.hu/80560/1/diplomaciai_lexikon.pdf (Letöltés időpontja: 2021. 04. 12.)
} 
Az állami és kormányzati vezetők diplomáciai protokolláris eseményein való részvétel:

Az állami és diplomáciai protokolláris feladatok jellemzően a köztársasági elnöki, a miniszterelnöki vagy a honvédelmi miniszteri hivatalos látogatások alkalmával, ill. azok programjában végrehajtott katonai tiszteletadással történő díszkíséret, díszsorfal és díszszemle (2. ábra). A honvédhuszárok tervezett létszáma (a fogadás helyétől függően) 8-16 huszár.

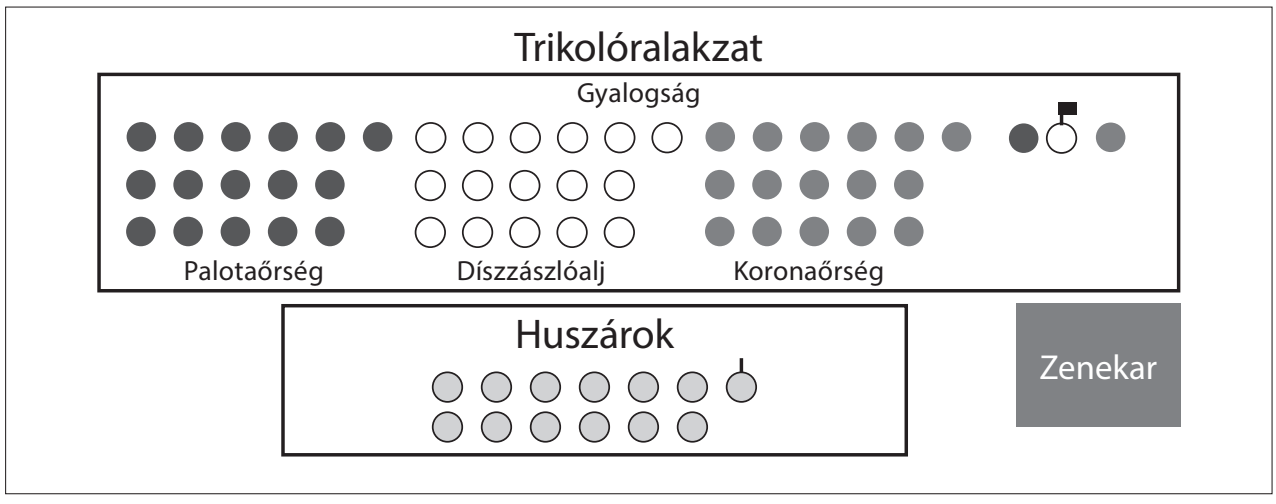

2. ábra Protokollalakzat összetétele (Készitette a szerzö)

Szintén köztársasági elnöki protokollesemény a nagyköveti megbízólevél-átadási ceremónia, amelynek során az Öreg huszár szobrától a nagykövetek huszár díszfelvezetéssel és díszkísérettel érkezhetnek a Köztársasági Elnöki Hivatalhoz. Ez a feladat a helyszín alapján 6 huszárral tervezhető.

\section{A Magyar Honvédség Parancsnokához köthetö katonai diplomáciai protokollfeladatok:}

A katonai diplomáciai protokolláris feladatok jellemzően a Magyar Honvédség parancsnokához érkező magas beosztású NATO- vagy más haderők parancsnokságáról érkező (vezérkari fönöki) hivatalos látogatások alkalmával, ill. annak programjában végrehajtott katonai tiszteletadással történő díszkíséret, díszsorfal, fogadás és díszszemle. A honvédhuszárok tervezett létszáma (a fogadás helyétől függően) 8-12 huszár.

\section{Egyéb jellegü protokollfeladatok lehetnek:}

A fentebb leírt állami vagy katonai diplomáciai protokollfeladatok keretén belül a különböző szintű delegációk programjába illeszthető a huszárok elhelyezési objektumában díszruházatban végrehajtott huszár lókiképzési vagy harcászati alaki bemutatók megtartása $2 \times 6$ huszárral, istállólátogatás vezetéssel vagy patkolókovács-bemutató (patkókészítés és lópatkolás).

Egyéb, protokolljellegủ feladat lehet a nyári időszakban (április 1. - október 31.), rendszeres protokolltevékenységként végezhetö, a Köztársasági Elnöki Hivatalnak és a Miniszterelnöki Hivatalnak helyt adó Budavári Palota területén a napi huszár díszjárőrszolgálat (3. ábra) 4 huszárral és a zenés huszárszemle $2 \times 4$ huszárral. 


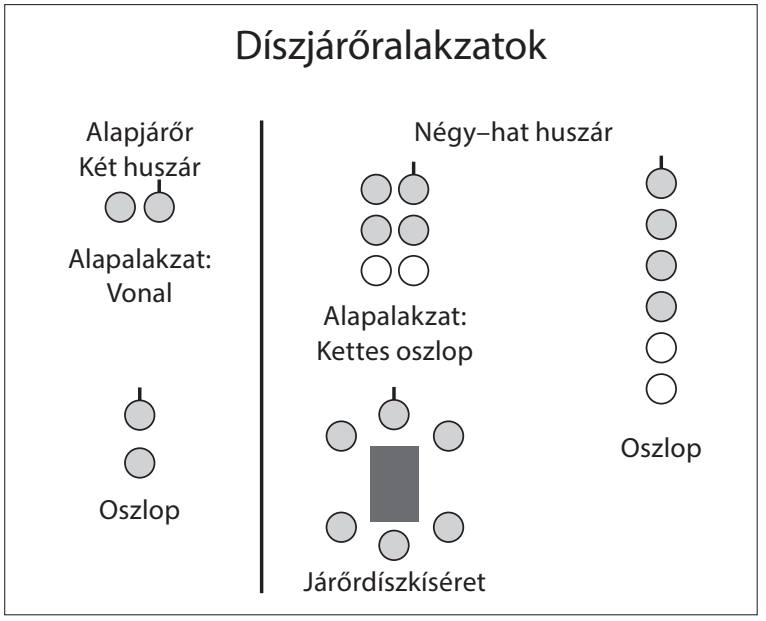

3. ábra Járör- és díszkíséret-alakzatok (Készitette a szerzö)

\section{ÖSSZEFOGLALÁS}

A huszárság mint a könnyülovasság egyik csapatneme megjelenésénél fogva reprezentatív alakulat, és békeidőben ceremoniális feladatokat hajt végre a 21. században is. Jó példa erre a dán haderő Gardehusarregimentjének (Gárdahuszárezred) lovasított százada, amely a Királyi Testörség mellett a királyi ház tagjainak közvetlen szolgálatában áll, hasonló protokolláris őrző-védő feladattal, mint a brit királynő Udvari Lovassága.

Hazai vonatkozásban a Kincsem Nemzeti Lovas Programban szereplő Honvéd Huszár Díszalegység létrehozásával és működtetésével megújuló honvédelmi rendszerünkben ismét megjelenik nemzeti történelmünk egyik katonaeszménye, nemzeti kultúránk, népmeséink, népdalaink és irodalmunk fontos szereplője, nemzettudatunk vitán felül álló közkedvelt alakja, hadtörténelmi múltunk legtisztább katonai és egyéni becsületen alapuló, legmagasabb harcértékű erkölcsiséggel bíró katonai alakulata. Reprezentatív részvételével a különböző protokolleseményeken hozzájárulhat a Budavári Palota komplexumhoz szervesen kötődő diplomáciai protokollesemények színvonalának emeléséhez. Ugyanakkor kiemelt jelentőséggel bírhat, hogy a magyar katonai lovaskultúra ápolásával és bemutatásával jelentős szerepet játszhat a nemzetközi szinten hazánkról kialakult országimázs erősítésében.

A hamvaiból 2020. július 1-jén feltámadó honvédhuszárság előtt még hosszú és kemény felkészülés áll annak érdekében, hogy a fenti célok megvalósulhassanak, de az úton elindult. Áldás a huszárra, áldás a lovára!

\section{FELHASZNÁLT IRODALOM}

1061/2012. (III. 12.) Korm. határozat a Nemzeti Lovas Programban meghatározott feladatokról és a kiemelt feladatok végrehajtásához szükséges intézkedésekről. Magyar Közlöny, 2012/29. http:// www.kozlonyok.hu/nkonline/index.php?menuindex=200\&pageindex=kozltart\&ev=2012\&szam=29

1er régiment de hussards parachutistes (Az 1. ejtőernyős huszárezred). https://www.defense.gouv.fr/ terre/1-armee-de-terre/le-niveau-divisionnaire/3e-division/11e-brigade-parachutiste/regiments/1erregiment-de-hussards-parachutistes 
1st Hussars (Az 1. huszárezred). http://www.army-armee.forces.gc.ca/en/4-canadian-division/1-hussars/ index.page

284/2018. sz. HVKF parancs. http://www.kozlonyok.hu/kozlonyok/index.php? $\mathrm{m}=0 \& \mathrm{p}=$ kozltart\&ev= 2018\&szam $=9 \& \mathrm{k}=13$

2011. évi CXIII. törvény a Magyar Honvédségről, valamint a különleges jogrendben bevezethető intézkedésekről. https://net.jogtar.hu/jogszabaly?docid=a1100113.tv

2e régiment de hussards (A 2. huszárezred). https://www.defense.gouv.fr/english/node_64/1-armee-deterre/le-niveau-divisionnaire/commandement-du-renseignement/2e-regiment-de-hussards

3/2019. (I. 31.) HM utasítás a honvédelmi szervezetek 2019. évi feladatainak, valamint a 2020-2021. évi tevékenysége fö irányainak meghatározásáról. http://www.kozlonyok.hu/kozlonyok/Kozlonyok/13/ PDF/2019/2.pdf

32. Nemzeti Honvéd Díszegység. https://bhd.honvedseg.hu/rovat/32_nemzeti_honved_diszegyseg

3e régiment de hussards (A 3. huszárezred). https://www.sengager.fr/regiments/3e-regiment-de-hussards

8th Canadian Hussars (A 8. kanadai huszárezred). http://www.army-armee.forces.gc.ca/en/5-canadiandivision/8-canadian-hussars/index.page

78/2011. (V. 12.) Korm. rendelet a Magyar Honvédség által védendő létesítmények kijelöléséről, valamint a magyar állam folytonosságát és függetlenségét megtestesítő ereklyék köréről és az őrzésükre vonatkozó szabályokról. https://net.jogtar.hu/jogszabaly?docid=a1100078.kor

Agrárminisztérium, miniszteri biztosok. https://kormany.hu/agrarminiszterium/miniszteri-biztosok

Diplomáciai lexikon. A nemzetközi kapcsolatok kézikönyve. Éghajlat Könyvkiadó Budapest, 2018, 621. http://real.mtak.hu/80560/1/diplomaciai_lexikon.pdf

Gardehusarregimentet (A Gárdahuszárezredről). https://forsvaret.dk/da/organisation/haeren/garde husarregimentet/

Gardehusarregimentets Hesteskadron (Gárdahuszárezred lovasított svadron). https://karriere.forsvaret. $\mathrm{dk} / \mathrm{uddannelse}$ /interne-uddannelser/hesteskadronens-varnepligt/

Görög Ibolya: Protokoll az életem. Athenaeum Kiadó, Budapest, 2017.

HM munkabizottsági jegyzőkönyv, 2015. 02. 20. Jkv sz. 61-74/2015.

Household Cavalry (Udvari Lovasság). https://www.army.mod.uk/who-we-are/corps-regiments-andunits/royal-armoured-corps/household-cavalry/

Kincsem - Nemzeti Lovas Program. Közigazgatási és Igazságügyi Minisztérium, 2012. http://mlosz. hu/nlp/nlp.pdf

MH BHD dandárparancsnok írásos jelentése. Nytsz. 510-20/2018.

Om Gardehusarregimentet (A Gárdahuszárezredről). https://forsvaret.dk/da/organisation/haeren/garde husarregimentet/om-os/

Regiment Huzaren van Boreel (A Boreel huszárezred). https://www.huzarenvanboreel.nl/

Sherbrooke Hussars (A Sherbrooke-i huszárezred). http://www.army-armee.forces.gc.ca/en/2-canadiandivision/the-sherbrooke-hussars/index.page

The King's Royal Hussars (A Király huszárezrede). https://www.army.mod.uk/who-we-are/corpsregiments-and-units/royal-armoured-corps/kings-royal-hussars/

The Queen’s Royal Hussars (A Királynő huszárezrede). https://www.army.mod.uk/who-we-are/corpsregiments-and-units/royal-armoured-corps/queens-royal-hussars/

The Royal Canadian Hussars (A királyi kanadai huszárezred). http://www.army-armee.forces.gc.ca/ en/2-canadian-division/the-royal-canadian-hussars/index.page 